\title{
Zniszczenie główki palnika stosowanego podczas cięcia przecinarką plazmową CNC
}

\author{
Destruction of a head of a torch used while cutting \\ with a CNC plasma cutter
}

\section{Streszczenie}

W artykule omówiono wybrane zagadnienia związane ze zniszczeniem końcówki palnika maszynowego, stosowanego w przecinarkach plazmowych CNC. Ukazano specyfikę cięcia plazmowego i problematykę ciągłej kontroli prowadzonego procesu. Zwrócono również uwagę na zachowanie się ciętego materiału w trakcie wprowadzania ciepła, które może powodować m.in. uwalnianie się naprężeń pozostających w materiale po walcowaniu. Artykuł obrazuje jak ważną kwestią są praktyczne szkolenia operatorów i programistów nie tylko w zakresie programowania i cięcia detali, ale również w przypadku załadunku i ściągania wycinanych elementów.

Słowa kluczowe: cięcie plazmowe; palnik; uszkodzenia

\begin{abstract}
Selected issues related to the destruction of a head of a machine torch used in the CNC plasma cutters are discussed in the article. The specifics of plasma cutting as well as a problem of a continuous control of the process are presented. An attention was also paid to the behavior of the material being cut during the heat input, which may cause, among others, a release of stresses remaining in the material after rolling. What is more, the article illustrates how important the practical training of operators and programmers is, not only in the field of programming and cutting details, but also in the case of loading and downloading of cut-out elements.
\end{abstract}

Keywords: plasma cutting; torch; damages

\section{Wstęp}

Obecnie istnieje wiele możliwości cięcia materiałów przewodzących i nieprzewodzących prąd elektryczny. Obserwując sytuację na rynku zauważa się ciągłą tendencję zmian i ulepszeń przecinarek plazmowych. Należy tutaj wspomnieć o maszynach podstawowych (standardowych), gdzie gazem plazmotwórczym jest sprężone powietrze, Hight Definition, Fine Plasma, cięciu z tzw. mgiełką wodną lub cięciu pod lustrem wody. To główne rozwiązania, które coraz częściej są stosowane.

Cięcie plazmowe jest procesem rozdzielania materiału za pomocą łuku plazmowego, jarzącego się pomiędzy elektrodą nietopliwą (hafn, tor, cyrkon) a materiałem. Skoncentrowany łuk elektryczny powstaje dzięki dyszy plazmowej, której niewielki otwór koncentruje ciepło na małej powierzchni. Dużą rolę w całym procesie odgrywa silnie zjonizowany gaz plazmotwórczy $[1,5,6]$.

Cięcie plazmowe (rys. 1) przecinarką CNC wiąże się z szeregiem operacji, jakie należy wykonać, aby móc we właściwy, a tym samym w bezpieczny sposób rozpocząć pracę. Począwszy od tych ściśle podstawowych (przygotowawczych), do których zaliczają się: włączenie zasilania (elektrycznego i gazowego), oględziny zewnętrzne urządzenia, skalibrowanie maszyny (czyli wczytanie punktu zerowego), załadowanie blachy na stół i w razie konieczności odpowiednie jej ustawienie, aż po główne: wczytanie programu przedstawiającego zarys danego elementu, wybranie parametrów pracy, rozpoczęcie wypalania i kontrola. Po wycięciu, detale zdejmowane są ręcznie (małe gabaryty) lub za pomocą suwnicy (w przypadku większych elementów). Ważnym elementem jest również usunięcie odpadów.

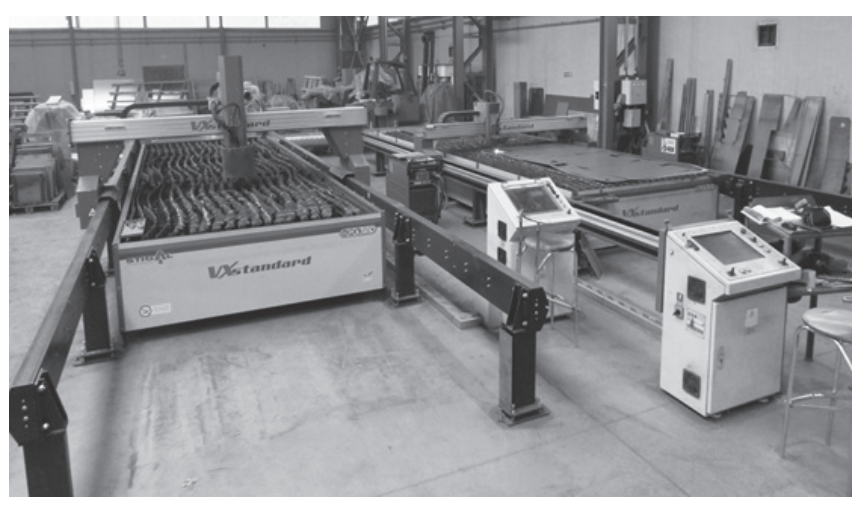

Rys. 1. Schemat procesu łączenia - główne etapy [2] Fig. 1. Self-piercing riveting outline [2]

Dr hab. inż. Jacek Słania, prof. PCz - Politechnika Częstochowska; mgr inż. Paweł Wilk - LOGITERM.

Autor korespondencyjny/Corresponding author: jacek_slania@poczta.onet.pl 
Opisując poszczególne zdarzenia skupiono się na przykładzie zakładu produkcyjnego, wyposażonego w przecinarki CNC, których gazem plazmotwórczym jest sprężone powietrze. Wykonywane przez firmę wyroby wymuszają konieczność umieszczania na blasze wielu elementów (również w celu maksymalnego wyeliminowania odpadów) o różnych gabarytach z regularnymi zmianami grubości ciętych materiałów (najczęściej 1 $\div 6 \mathrm{~mm}$ a sporadycznie do $20 \mathrm{~mm}$ ). Taka sytuacja powoduje, że stół (ustawienie żeber, na których leży blacha) musi być uniwersalny, czyli może być stosowany przy cięciu zarówno przy małych, jak i dużych detali.

Praca na stanowisku operatora przecinarki plazmowej CNC (rys. 1) wiąże się zatem z koniecznością ciągłej kontroli (nadzoru) realizowanego procesu. Warto wspomnieć, że w zależności od grubości przecinanego materiału, prędkość cięcia zmienia się; czyli im grubsza blacha tym prędkość cięcia będzie mniejsza. Nie znaczy to, że pracownik może opuścić stanowisko zostawiając uruchomione urządzenie; niebezpieczne w niektórych przypadkach mogą być przyspieszone przejazdy pomiędzy wycinanymi elementami.

Sam proces cięcia plazmowego składa się z kilku etapów [2]:

- najazd ruchem przyspieszonym w odpowiednie miejsce na arkuszu, od którego rozpocznie się cięcie;

- obniżenie palnika, dotknięcie blachy i podniesienie go do wysokości umożliwiającej zajarzenie łuku pilotującego;

- zajarzenie łuku głównego;

- przebicie blachy przez tuk plazmowy;

- kontrola i stabilizacja łuku plazmowego;

- kontrola i regulacja odpowiedniej wysokości palnika od blachy;

- rozpoczęcie ciecia;

- kontrola procesu;

- zakończenie cięcia;

- podniesienie palnika;

- przejazd ruchem przyspieszonym w kolejne miejsce.

Na rysunku 2 przedstawiono przykładowy schemat ruchów palnika po rozpoczęciu cięcia.

W związku z tym, że podczas procesu cięcia dochodzi do szeregu zjawisk, istnieje pewne niebezpieczeństwo uszkodzeń czy zniszczenia palnika (rys. 3). Najczęściej są one spowodowane:

- błędem ludzkim: nieodpowiednio przygotowany program, nieprzystosowany program w stosunku do usytuowania żeber, na których leży materiał czy uderzenie zakładaną lub ściąganą blachą (detalem);

- czynnikiem zewnętrznym: uwolnieniem naprężeń w materiale podczas cięcia, niekontrolowanym zachowaniem urządzenia (błędem);

- mają charakter przypadkowy.

Zniszczenie główki palnika, najczęściej wiąże się koniecznością jego wymiany na nowy. Jakiekolwiek próby regeneracji są zabronione i grożą utratą gwarancji, a nawet uszkodzeniem urządzenia.

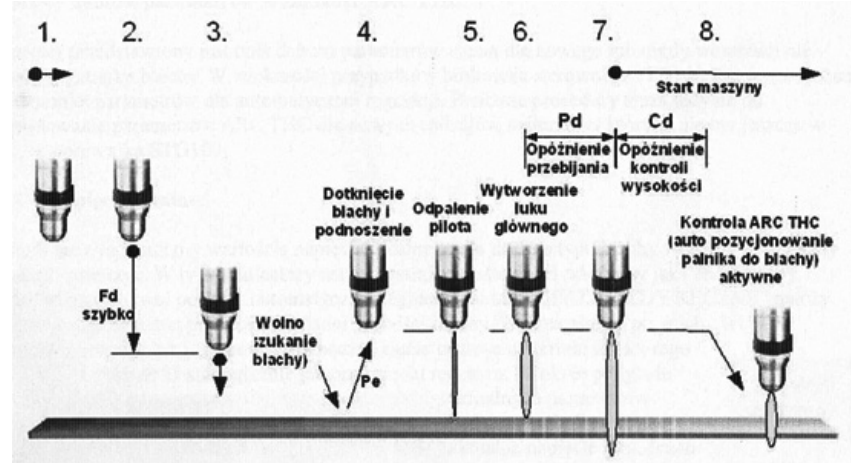

Rys. 2. Schemat ruchów palnika po zainicjowaniu cięcia [2]

Fig. 2. Diagram of a torch motions after initiating a cutting process [2]

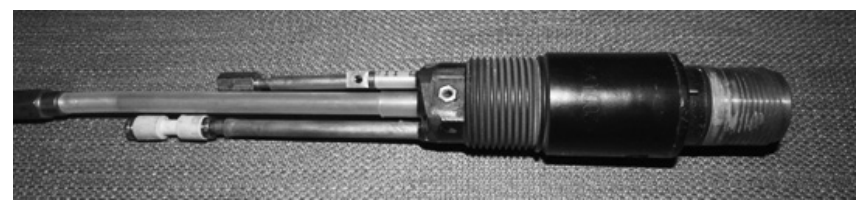

Rys. 3. Nowy palnik do ciecia plazmowego chłodzony cieczą Fig. 3. New liquid-cooled plasma cutting torch

\section{Zniszczenie palnika spowodowane przegrzaniem}

Jeśli nie ma zapewnionego całodobowego ogrzewania hali produkcyjnej (miejsca, w którym znajduje się przecinarka) do chłodzenia należy zastosować płyn niezamarzający na bazie glikolu lub innego składnika, zgodnie z zaleceniem producenta źródła prądu. Przy długo utrzymującej się temperaturze ujemnej na zewnątrz oraz w przypadku dłuższego zatrzymania produkcji np. w okresie między świątecznym, może dojść do zamarznięcia cieczy chłodzącej w cienkich przewodach, łączących agregat plazmotwórczy z palnikiem. Rozpoczęcie cięcia spowoduje szybkie przegrzanie palnika, a tym samym jego zniszczenie.

Aby temu zapobiec operator powinien włączyć zasilanie agregatu i sprawdzić, czy pompa transportuje ciecz do zbiorniczka. Nieuczynienie tego skutkowało awarią urządzenia i zniszczeniem palnika (rys. 4). Inny palnik, który został uszkodzony w podobnych okolicznościach przedstawiono na rysunku 5.

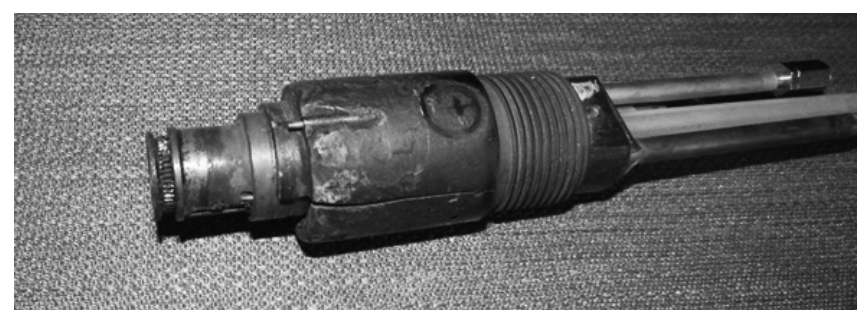

Rys. 4. Efekt pracy bez chłodzenia palnika - widoczny brak głowicy Fig. 4. Effect of work without cooling a torch - a lack of a head is visible

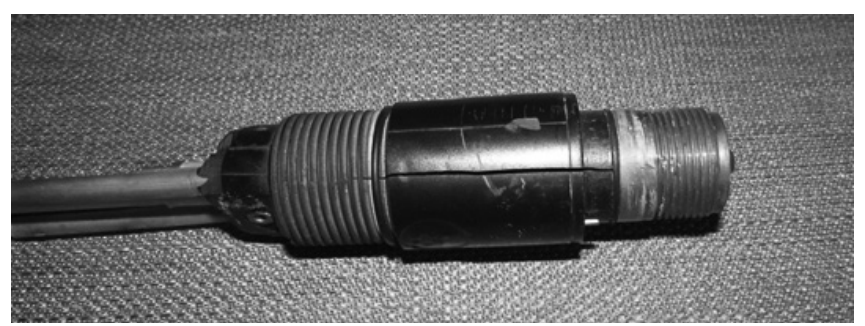

Rys. 5. Nowy palnik do ciecia plazmowego chłodzony cieczą Fig. 5. New liquid-cooled plasma cutting torch

\section{Zniszczenie palnika spowodowane uderzeniem podczas załadunku blachy/ zdejmowania wypalonych detali}

Z reguły na portale (stoły) plazmowa blacha o większych gabarytach jest transportowana za pomocą suwnicy. W takim przypadku przed załadunkiem/zdjęciem należy oddalić się suportem na skrajnie najdalsze położenie, aby przygotować miejsce do manewrowania blachą. W omawianej sytuacji pracownik zatrzymał suport zbyt blisko ciętych blach, dodatkowo wózek wciągarki suwnicy nie znajdował się w osi ściąganego detalu; podczas podnoszenia elementu nastąpiło uderzenie blachą o palnik (niewiele brakowało, a zostałby uszkodzony suport). Siła uderzenia doprowadziła do złamania (rys. 6) i rozszczelnienia palnika, a także wycieku płynu chłodzącego. 


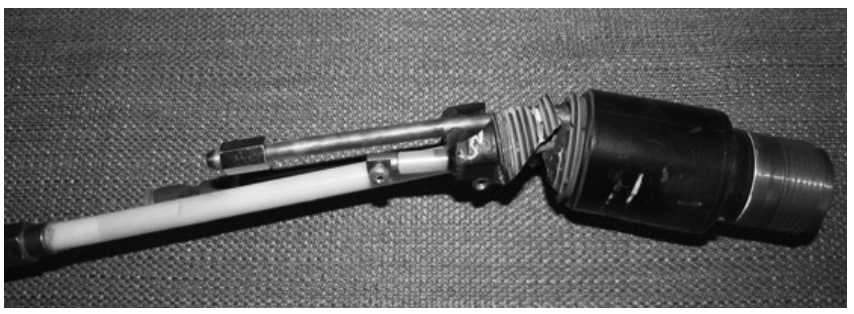

Rys. 6. Złamany palnik

Fig. 6. Broken torch

\section{Zniszczenie palnika spowodowanego zderzeniem (zahaczeniem) o wycięty wcześniej element podczas cięcia}

Cięcie plazmowe pozwala na cięcie dużej liczby elementów o skomplikowanych kształtach, które można umieścić na arkuszu blachy. Oczywiście, aby cięcie było najbardziej ekonomiczne (z minimalną ilością odpadu), miejsca niezagospodarowane elementami głównymi uzupełnia się mniejszymi detalami (potrzebnymi w dalszym toku produkcji). Wycięte części mogą mieć skłonność do przechylania się i wpadania pomiędzy żebra, na których leży blacha. W zależności od producenta urządzenia, a także potrzeb produkcyjnych danego zakładu, żebra te mają różne kształty i kierunki (mogą być skierowane również pod różnymi kątami), jak również odległości pomiędzy nimi mogą być inne.

Do zniszczenia palnika doszło w momencie, gdy wycięty wcześniej detal przechylił się i wystając ponad blachę nachodził na pozostałą (nieobrobioną jeszcze) część arkusza. Operator tego nie zauważył i podczas cięcia kolejnego elementu (sąsiadującego), palnik najechał na wystający detal, efektem czego było jego skrzywienie.

W związku z tym, że prędkość cięcia była niewielka, operator miał możliwość wyłączenia i zatrzymania procesu - ale akurat w momencie kolizji był zajęty rozmową z innym pracownikiem.

Palnik po dokładnych oględzinach i stwierdzeniu poważnych uszkodzeń wewnętrznych został skierowany do zezłomowania, podobnie jak połamana tuba (rys. 7).

Odległości pomiędzy żebrami powinny być dostosowane do wielkości wycinanych elementów, np. przy wycinaniu drobnych detali odstępy muszą być dużo mniejsze, tak aby zapobiec wpadaniu ich pomiędzy (ryzyko uszkodzenia palnika lub wspomnianych części poprzez nacięcia itp.).
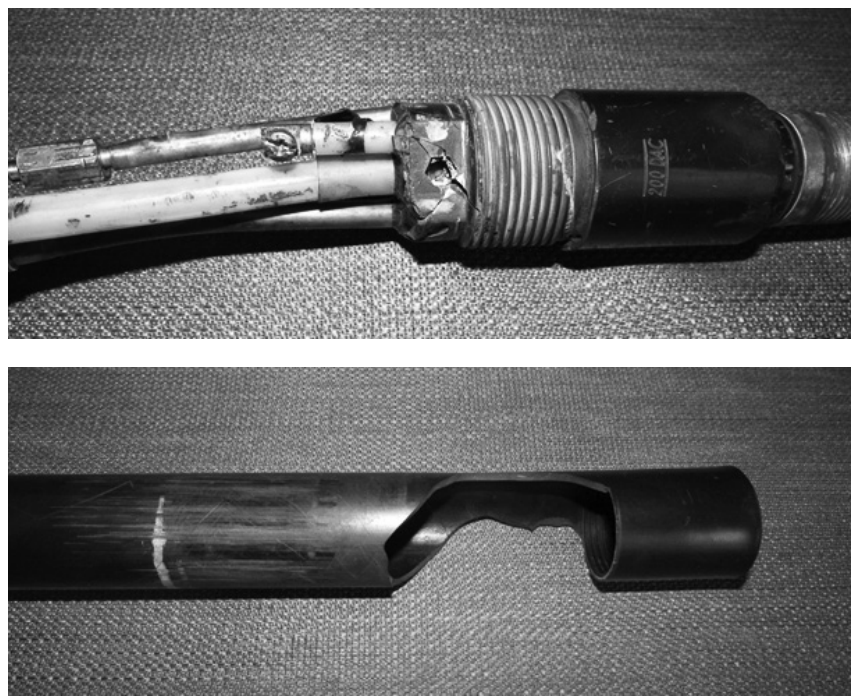

Rys. 7. Uszkodzony palnik i tuba przytrzymująca go w suporcie Fig. 7. Damaged torch and a tube holding it in the support
Niewielkie odległości stwarzają konieczność szybszej ich wymiany z racji intensywniejszego nacinania łukiem plazmowym, a dodatkowo wymuszają częstsze czyszczenie przestrzeni między nimi (nieusuwana wypływka wraz z innymi odpadami utrudnią właściwą wentylację stołu plazmowego, a także powodują problemy z równym, płaskim ułożeniem blachy). W niektórych miejscach arkusz może nie mieć podparcia (rys. 8).

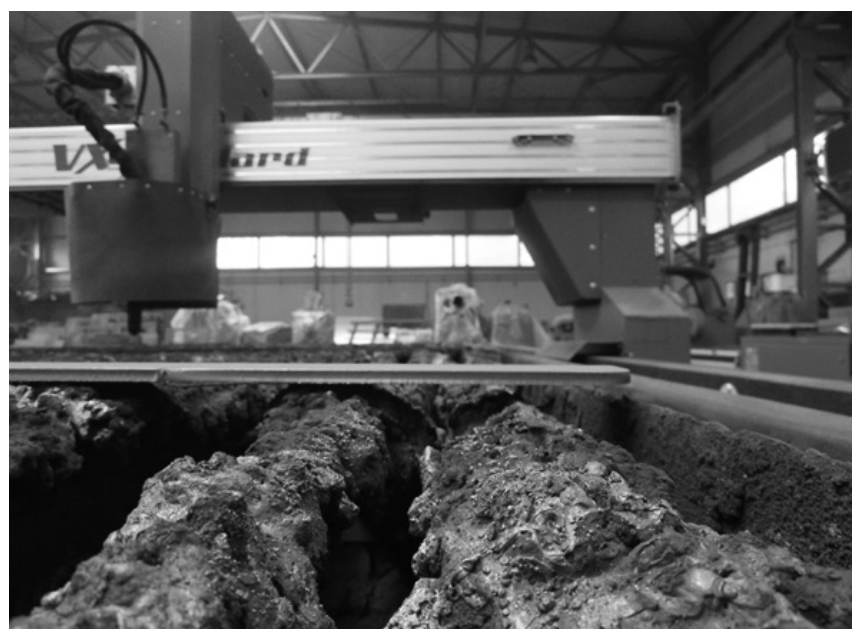

Rys. 8. Brak równomiernego podparcia ciętego materiału, spowodowana m.in. nadmierną ilością wypływki nagromadzonej na żebrach Fig. 8. Lack of a steady support of the material being cut, caused by, among others, an excessive amount of flashing accumulated on the fins

\section{Zniszczenie palnika spowodowane zahaczeniem o wystający element przy przejeździe ruchem przyspieszonym}

Tak jak wspomniano, cięcie plazmowe wymaga nie tylko czujności operatora, ale również determinuje programistę do przemyślanego tworzenia programów. Osoba programująca ułożenie detali na arkuszu podczas projektowania musi wiedzieć jak zbudowane jest urządzenie. Dodatkowo powinna przewidywać, co może się stać w danej chwili i czy w ogóle przecinarka, a także operator, są w stanie wyciąć dany element (grupę elementów) bez komplikacji. Podobnie jest z pracownikiem; myślący operator (fachowiec) po spojrzeniu na rozmieszczenie detali i umieszczeniu zajarzeń łuku potrafi określić potencjalne miejsca, gdzie mogą pojawić się problemy.

W omawianym przypadku doszło do nałożenia się na siebie kilku kwestii.

Nieprawidłowo rozlokowane podłużne elementy na arkuszu, obszary cięcia umieszczone w nieodpowiednim miejscu, ustawienie żeber (rys. 9) na stole przecinarki równolegle do dłuższego boku i brak kontroli osoby realizującej program cięcia.

Palnik z punktu zerowego przejechał w okolicę środka pierwszego detalu, aby go napunktować. Następnie przemieścił się do miejsca wcięcia i zaczął wycinać element. Po wycięciu, zgodnie z ustaloną trajektorią miał przejechać ruchem przyspieszonym do środka detalu drugiego, aby go napunktować. W tym samym momencie wycięty element 1 wpadając między żebra spowodował natychmiastowe zablokowanie palnika, jego rozszczelnienie, naruszenie miejsc przyłączenia przewodów elektrycznych i zniszczenie tuby (rys. 10). Trwało to ułamek sekundy i nie było żadnej możliwości zatrzymania procesu.

Siła uderzenia (zahaczenia) była tak duża, że spowodowała rozszczelnienie łącznika doprowadzającego ciecz chłodzącą do palnika. 


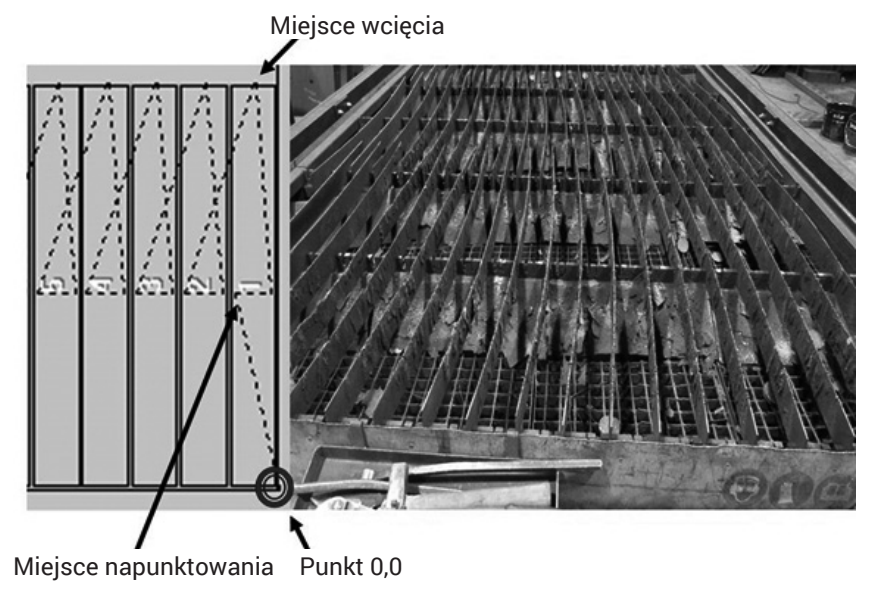

Rys. 9. Po lewej: Wydruk z programu WRYKRYS (ustawienie elementów wzdłuż stołu); Po prawej: umiejscowienie żeber na portalu przecinarki plazmowej

Fig. 9. On the left: a print from the WRYKRYS programme (setting elements along the table); on the right: placement of the fins on the plasma cutting portal
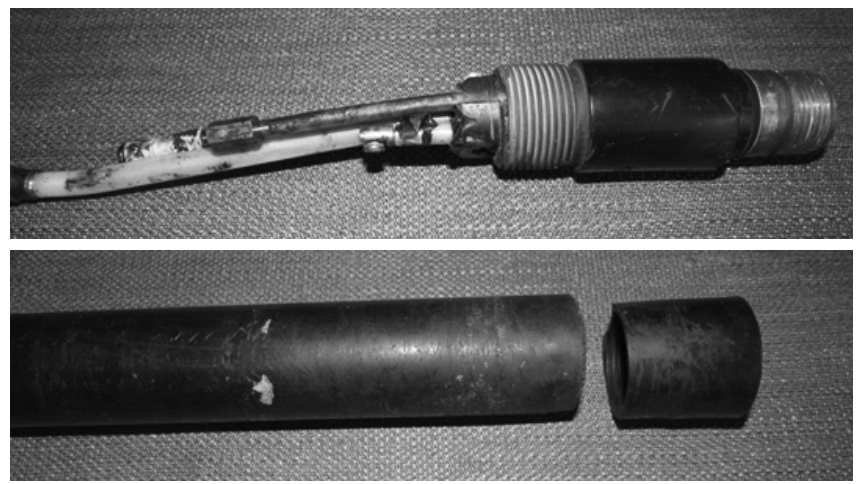

Rys. 10. Zgięty palnik i zniszczona tuba

Fig. 10. Bent torch and a destroyed tube

Aby uniknąć takiego zdarzenia, detale powinny być ustawione prostopadle do żeber, a jeśli nie ma takiej możliwości, należy zmienić punkt wcięcia łuku plazmowego. Najlepszym rozwiązaniem jest jednak zmiana ustawienia żeber i przestawienie ich o pewien kąt np. $45^{\circ}$ (rys. 11). Takie usytuowanie zapobiegnie wpadaniu dłuższych, ale smuklejszych detali.

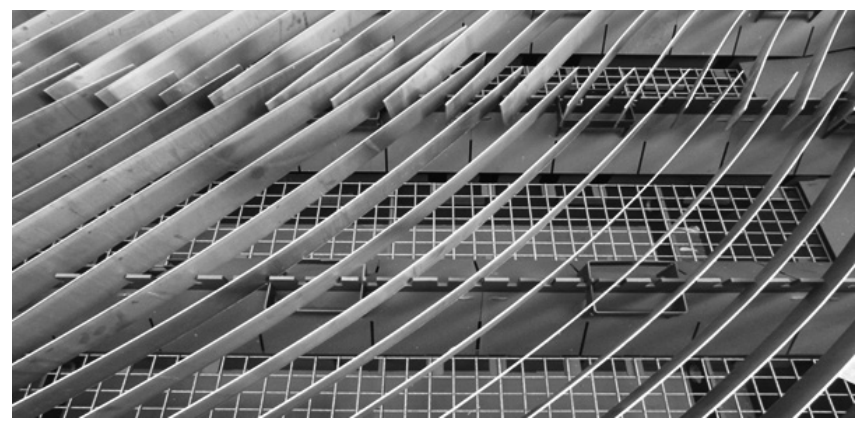

Rys. 11. Użebrowanie stołu plazmowego - kąt ok. $45^{\circ}$

Fig. 11. Plasma table finning - angle of about $45^{\circ}$

\section{Zniszczenie dyszy plazmowej i osłony głowicy}

Cięcie plazmowe powoduje wprowadzenie do materiału dużej ilości ciepła. Uzależnione jest to od grubości blachy, a także prędkości samego procesu. Ciepło połączone z rozdzielaniem materiału na mniejsze elementy niejednokrotnie powoduje, że w trakcie ujawniają się naprężenia znajdujące się w stali. Uwolnienie ich prowadzi do odkształceń poszczególnych detali. Bardzo często w takiej sytuacji po zakończeniu cięcia element energicznym ruchem odbija i uderza w palnik od spodu, uszkadzając tym samym dyszę gazową. Nagłe zmiany wysokości stwarzają możliwość zetknięcia otworu dyszy z materiałem, co spowoduje jej uszkodzenie (rys. 12). Inny element, jakim jest głowica osłonowa, zużywa się poprzez oddziaływanie wysokiej temperatury, jak również przez uszkodzenia mechaniczne (zahaczanie bokami o wystające, rozgrzane elementy)(rys. 13).

Zachowanie wyciętego elementu może być bardzo różne. Wiele zależy od gatunku materiału, grubości, a także od procesu wytwarzania. Dzięki odpowiednim czujnikom palnik obniża się (lub podnosi), tak aby zachować podaną długość łuku plazmowego albo wartość napięcia. Odległość palnika jest wprost proporcjonalna do długości łuku - im odległość jest większa, tym napięcie jest większe i odwrotnie.
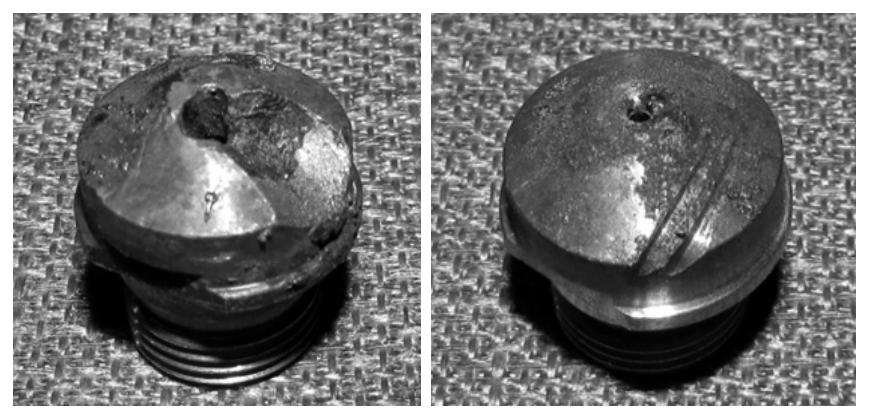

Rys. 12. Dysze plazmowe: po lewej - uszkodzenie spowodowane chwilowym zetknięciem dyszy z materiałem; po prawej - widoczne dwa rowki, które są wynikiem kontaktem o wystające elementy

Fig. 12. Plasma nozzles: on the left - a damage caused by a temporary contact of a nozzle with the material; on the right - two visible grooves, which are the result of a contact with protruding elements
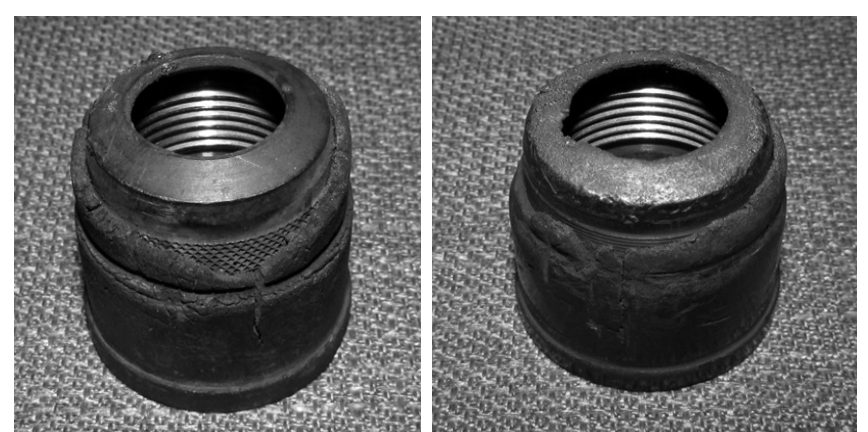

Rys. 13. Głowice osłonowe

Fig. 13. Cover heads

Wspomniane zjawiska dotyczące uwalniania się naprężeń własnych spowodowane są poprzez lokalne nagrzewanie blachy [3], a także są wynikiem procesu walcowania blachy w hucie [4]. Należy podkreślić, że odkształcenia detali podczas cięcia są kwestią problematyczną z kilku powodów: utrudniają cięcie, mogą powodować przesuwanie się danych elementów na stole plazmowym (uszkadzając je), czy doprowadzić do zniszczenia palnika lub jego elementów.

Problem z odkształcaniem blach jest spotykany głównie przy cięciu cieńszych materiałów - oczywiście istotne są również ich gabaryty, im blacha grubsza tym jej sztywność jest większa. Występowanie naprężeń i odkształceń nie jest jednak tak oczywiste i powtarzalne. Wielokrotnie nie pojawiają się żadne komplikacje podczas pracy, innym razem odkształcenia mogą sięgać nawet kilkudziesięciu milimetrów w pionie, co powoduje konieczność zatrzymywania i ponownego wznawiania pracy (rys. 14). Jest to uciążliwe i może powodować zdeformowanie/uszkodzenie powierzchni cięcia, co z kolei wymusi zastosowanie obróbki mechanicznej, a w niekorzystnych okolicznościach konieczność naprawy (poprzez napawanie) lub ostatecznie zezłomowanie. 


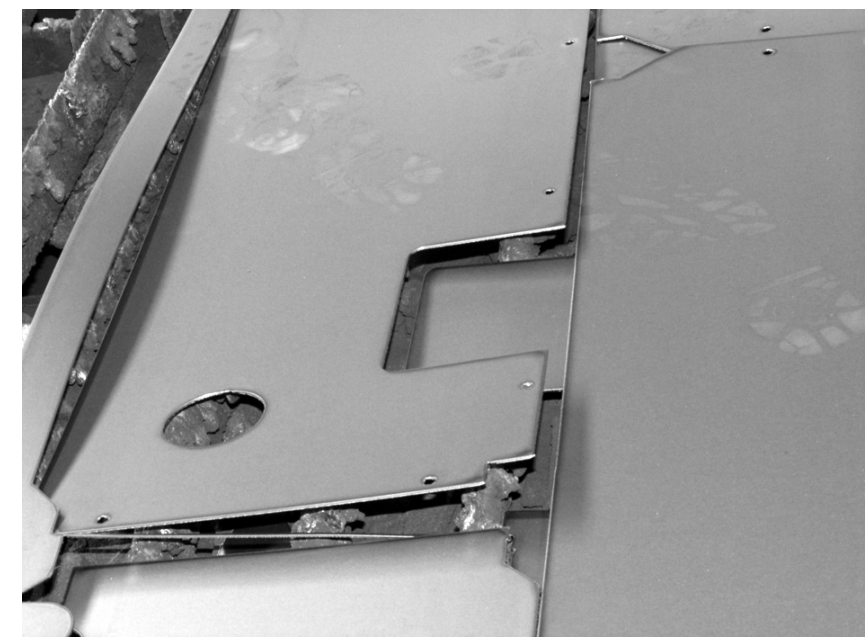

Rys. 14. Znaczne odkształcenie wypalanych blach o grubości $1 \mathrm{~mm}$ Fig. 14. Significant deformation of burnt sheet metal of $1 \mathrm{~mm}$ thick

Zabezpieczenie przed kolizją z materiałem jest bardzo trudne, ponieważ czym innym jest lekkie, wolne dotknięcie albo zbliżenie się materiału do palnika (wówczas najczęściej zadziała system antykolizyjny, jeśli dane urządzenie jest wyposażone), a czym innym zaś nagłe uderzenie z dołu lub boku.

W związku z powyższym ważna jest odległość dzieląca osłonę od materiału ciętego (której zadaniem jest zasłonięcie łuku plazmowego), ponieważ jeśli jest zbyt blisko blachy to uniemożliwia operatorowi zaobserwowanie nieprawidłowości (rys. 15).

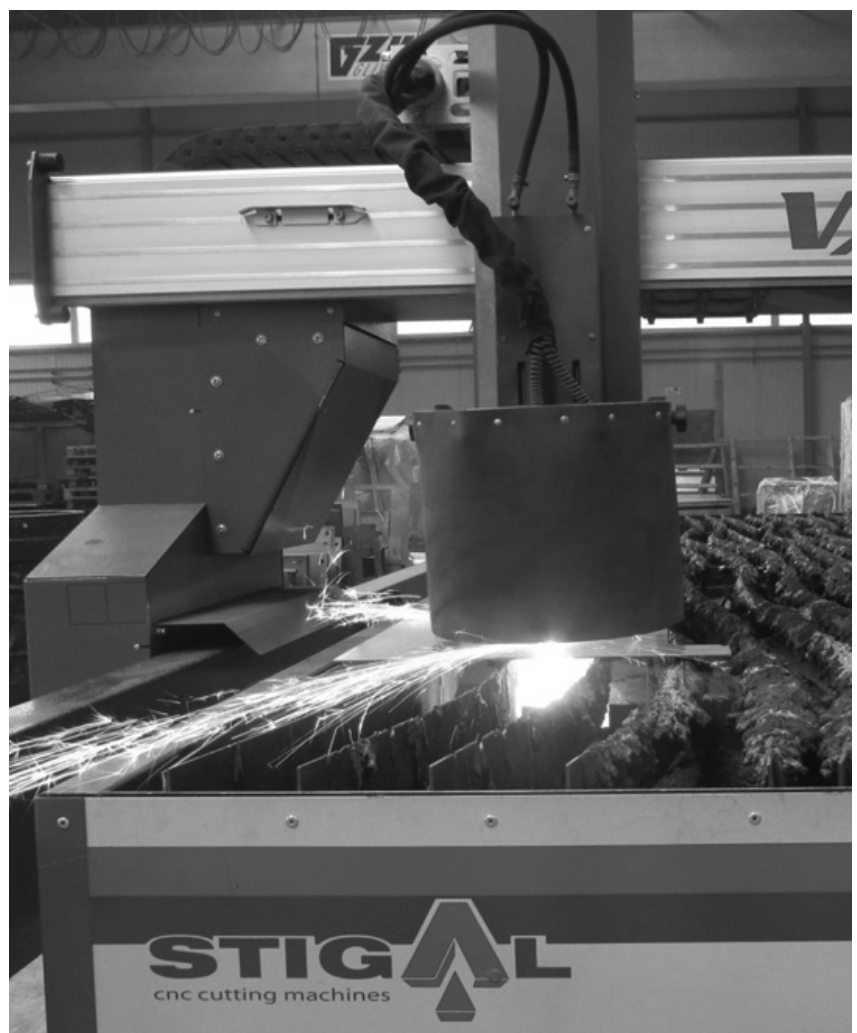

Rys. 15. Zbyt niskie opuszczenie osłon mogą uniemożliwiać dobrą obserwację

Fig. 15. Moving down the covers too low may prevent a proper observation

\section{Podsumowanie}

Reasumując, cięcie plazmowe jest operacją, podczas której może dojść do zniszczenia palnika, jego elementów a czasem także ciętego materiału. Częstym powodem takiego stanu rzeczy są błędy ludzkie, m.in. brak wyobraźni, nieumiejętność przewidywania pewnych zachowań zarówno urządzenia, jak i materiału ciętego, czy w końcu nieodpowiednia kontrola samego procesu. Omówione zdarzenia mogą generować niepotrzebne koszty związane z wymianą główki palnika (podzespołów), straty związane z ewentualnym złomowaniem danego detalu, jak również konieczność zatrzymania toku produkcyjnego i przeprowadzenie naprawy. Dobrym zwyczajem jest wprowadzenie zasady, aby po każdym takim zdarzeniu, przeanalizować sytuację i określić, dlaczego do tego doszło i jak w przyszłości można temu zapobiec. Nie bez znaczenia są także szkolenia poszczególnych pracowników i uczulanie ich na konkretne sytuacje.

\section{Literatura}

[1] Praca zbiorowa: Poradnik inżyniera Spawalnictwo, Tom 2, Wydawnictwa Naukowo-Techniczne, Warszawa 2003.

[2] Instrukcja obsługi przecinarki plazmowej STIGAL VX STANDARD

[3] Słania J.: Plany spawania. Teoria i praktyka. Agenda Wydawnicza SIMP Redakcja Przegląd Spawalnictwa, Warszawa 2013.

[4] Ferenc K., Ferenc J.: Konstrukcje spawane. Połączenia. Wydawnictwa Naukowo-Techniczne, Warszawa 2006.

[5] Vanschen W.: Plasmaschneiden - Teil 1Prinzip, Düsengeometrien, Gase. DER PRAKTIKER, 2004, t. 56, nr 1, s. 22-24.

[6] Vanschen W.: Plasmaschneiden - Teil 2 Leistungs - und Qualitätsbeeinflussungen, Arbeitssicherheit und Gesundheitsschutz. DER PRAKTIKER, 2004, t. 56, nr 2, s. 48-51. 